\title{
Effects of Flood on Food Security, Livelihood and Socio-economic Characteristics in the Flood-prone Areas of the Core Niger Delta, Nigeria
}

\author{
D. A. Week ${ }^{1}$ and C. H. Wizor ${ }^{1 *}$ \\ ${ }^{1}$ Department of Geography and Environmental Management, University of Port Harcourt, \\ Port Harcourt, Nigeria.
}

Authors' contributions

This work was carried out in collaboration between both authors. Author DAW designed the study and performed the statistical analysis. Author CHW wrote the protocol, wrote the first draft of the manuscript, managed the analyses of the study and the literature searches. Both authors read and approved the final manuscript.

Article Information

DOI: 10.9734/AJGR/2020/v3i130096

Editor(s):

(1) Dr. Xu Chong, Professor, Institute of Geology, China Earthquake Administration, China

Reviewers:

(1) Md Nazirul Islam Sarker, Neijiang Normal University, China.

(2) Rose Edwin Daffi, University of Jos, Nigeria.

(3) Seyit Hayran, Cukurova University, Turkey.

Complete Peer review History: http://www.sdiarticle4.com/review-history/53627

Original Research Article

Received 01 November 2019

Accepted 06 January 2020

Published 14 January 2020

\begin{abstract}
The study examined the effects of flood risk levels on food security, livelihood and socio-economic characteristics in the flood-prone areas of the core Niger Delta, Nigeria using a descriptive survey design and 790 respondents were selected with the aid of a multistage stratified sampling technique in Bayelsa, Delta and Rivers States, representing the core Niger Delta. Descriptive statistics were used in the analysis and presentation of data. The findings of the study showed that $75.3 \%$ of the respondents agreed that basic food is scarce after all flood incident. However, $69.9 \%$ attested to the fact that growth and development of crops are affected when flood washes away farmlands. It can also be seen that flood increases food insecurity, unavailability of staple food and malnutrition as agreed by $78.3 \%$ of the total respondents. Furthermore, $77.1 \%$ of respondents agreed that flood increases the inability of plants to absorb essential nutrients necessary for proper growth while $71.4 \%$ agreed that flooding leads to the erosion or loss of the nutritional status of crops planted in the communities. Also, $69.9 \%$ agreed that the washing away of farmlands have led to chronic, long-
\end{abstract}


lasting food insecurity in the communities. Further evidence from the study shows that $75.6 \%$ of respondents agreed that the incident of flood leads to acute food insecurity which affects the livelihood of the residents. It is also revealed that flood affects households or residents' investments $(64.7 \%)$ and losing occupation and source of income from flooding leads to difficulty in caring for the children $(60.9 \%)$. It is concluded that floods have reduced the efficiencies of farmland in terms of food production causing food insecurity, income reduction and poor livelihood among the residents of the core the Niger Delta States. The study, therefore, recommended that communities should advocate, promote and inculcate the spirit of the commitment of individuals and households towards the continued and holistic development (via social, economic, health, and infrastructural), food security, and increased livelihood in flood-prone communities. The Ministry of Agriculture should ensure that smart agriculture is adopted as a way out to resolve the issues of flood-induced food insecurity and structural measures like dams, culverts, drainages and ditches should be constructed by government and her intervention agencies to accommodate and reduce the runoff or overflow of floodwaters which causes severe social, economic and infrastructural damages or impacts during flooding.

Keywords: Core Niger Delta; flood; flood-prone areas; food security; livelihood; Nigeria; socioeconomic.

\section{INTRODUCTION}

In contemporary times, flood hazards have been categorized among the most devastating natural hazards in the world, claiming more lives and causing more property damage than any other natural or man-made hazards. As a result, floods are perceived as one of the greatest challenges to weather prediction by climate experts. Flooding is an overflow of a body of water that inundates the land. When a bank is overtopped, the water spreads over the flood plain and generally becomes a hazard to society leading to a great number of damages and loss of lives. It is an extreme meteorological event which can occur in areas characterized by a high degree of urbanization or rural enclaves.

The issue of climate change has increased the severity and rate of occurrence of the flood disaster, with its negative impact on food production, food distribution, food utilization, and food security [1]. Several pieces of literature tend to suggest that households, particularly those in sub-Saharan Africa, are vulnerable or food insecure due to limited economic and physical capacities as well as an environmental disaster caused by flooding. It is generally believed that poor farmers' households are vulnerable to flooding events. Thus, a presently food-secure household cannot be guaranteed the same status in the coming season because of the unpredictable nature of flooding events. Consequently, Jeronim, et al. [2] opined that the notion of food security is a dynamic rather than a static phenomenon depending on the prevailing economic, physical and climatic circumstances.
The amount of damage caused by a flooding event to a large extent depends on its severity and how long it lasts, and on the reliability and availability of measures put in place by the government or local people to receive the flood. Nwaobiala and Nwosu [3] maintained that agriculture is one of the most weather-dependent human ventures. Agriculture suffers due to its vulnerability to climate change and African countries are particularly vulnerable to the incidences of climate given their dependence on rain-fed agriculture. FAO [4] and BNRCC [5] agrees that the positive and negative effects of climate include but not limited to the extended growing season, enhanced livestock production, constraint to primary and secondary productivity and crop failure. Gichere et al. [6] noted that in sub-Saharan Africa, droughts and floods are two extreme climatic events that adversely affect the agricultural sector, and by extension affect the household food consumption.

Household food insecurity, on the other hand, has been classified as either persistent or transitory. Persistent food insecurity signifies continuous food crisis caused by the continual inability of households to acquire needed food, either through market purchases by money or through own production as farmers [7]. On the other hand, transitory food insecurity is a temporary decline in a household's access to needed food due to instability in food prices, production or income. It signifies a short time inadequacy in households to meet food requirement, which obligates the vulnerable households to devise coping mechanisms to bridge their food consumption gap. Whether 
persistent or transitory, food insecurity remains a great problem to developing countries particularly, in sub-Saharan Africa which accounts for a significant share in the World's population.

A recent study in Bangladesh by Alam et al. [8] examined the impact of climate-induced hazards on livelihood and food security, and the way susceptible households respond to it. The study developed a Food Security Index (FSI) to improve understanding of the extent of households' food insecurity where 3 indicates food security and 1 minimal security.

Agriculture overtime has remained one of the most vulnerable sectors to climate change in Africa, particularly in terms of declines in agricultural production and uncertain climate that significantly affects food security [9]. Despite this fact, agriculture has remained an important source of livelihoods on the continent. Studies have shown that an average of $70 \%$ of the population in Africa, lives by farming; $40 \%$ of all export earnings come from agriculture and about one-third of the national income in Africa is generated by the agricultural sector [10].

The poorest members of the society in African countries are those most dependent on rain-fed subsistence agriculture for food, jobs and income, and hence the most vulnerable to climate change [11].

Food security is a complex phenomenon and may be seen as an integration of three core dimensions i.e. food availability, accessibility and utilization [4]. The problem of food insecurity is not only caused by an insufficient supply of food but also due to the lack of purchasing power and access at national and household levels. Therefore, despite gains in global food production and food security over the last three decades, more than 800 million people are undernourished and almost all of them belong to the developing countries of the world $[12,4]$. More so, growing population coupled with increased intensity of environmental extreme events like floods, droughts, extreme variability in temperature and rainfall has increased the pressure on the current food production systems which in turn, has threatened the current food security crisis in most of the developing countries [13]. Due to higher food demands and reduced crop productivity, the higher food prices may further negatively affect the food access and availability for low income and already poor households [14].

Contemporary food insecurity has been a global issue with the Niger Delta region of Nigeria not been an exception. In addition to the direct threats posed to individuals' livelihoods by food insecurity, it also further compounds the other environmental, socio-economic, and physical threats facing the people. It is therefore critical to pay attention to food security, in addition to the vast amount of resources and attention expended on checking the resurgence of violence in the oil-rich but impoverished region [15]. For many developing countries in the world, flood brings new opportunities for livelihoods, e.g., floodwater brings fishes to fisherman and brings new fertile soil for agriculture. Therefore, while it is important to reduce the negative impacts of flood, the positive aspects of the flood have urged people and communities in the vulnerable areas to develop the notion "living with a flood" or "coping with a flood".

In Nigeria, the most persistent environmental challenge remains flood which normally occurs when flowing water submerges land areas that were not subjected to inundation before. Explicitly, flooding is an outcome of land inundation with water attributed to the rise in water or the inability of an aquatic ecosystem to hold excess water. Several reports of an outbreak of epidemic disease and various waterborne diseases add to the contamination of water supplies due to flooding. Several anthropogenic activities have contributed to worsening the event of flood disaster; such activities include industrialization, urbanization, population growth, utilization of environmental resources and infrastructural development. Agbonkhese, et al., [16] and Agbonkhese, et al., [17] posited that unlawful dropping of wastes, blockage and poor water evacuation system are causal-factors of flooding in Nigeria. The general process of disaster management involves real-time disaster information collections, compilations, interpretations, analyses, predictions, illustrations and decision support.

Food security practice and livelihood in the floodprone areas of Niger Delta is threatened by several regional challenges. Known previous studies in the delta did not combine food security, livelihood and socio-economic characteristics. In addition to the direct threats posed to individuals' livelihoods by food insecurity, it also further compounds the other 
environmental, socio-economic and physical threats facing the people. It is therefore critical to pay attention to food security, in addition to the vast amount of resources and attention expended on checking the resurgence of violence in the oil-rich but impoverished region [15]. Against this background, the present study seeks to fill this gap in knowledge by examining the effects of flood risk on food security, livelihood and socio-economic characteristics of people in the flood-prone areas of the core Niger Delta, Nigeria.

\section{STUDY AREA}

The study was carried out in the Core Niger Delta of Nigeria comprising Bayelsa, Delta and Rivers States (Fig. 1). These states were selected because of the frequent occurrence of the flood being experienced annually. The Core Niger Delta is located on the latitudes $4^{\circ} 30^{\prime} 00^{\prime \prime} \mathrm{N}$ and $6^{\circ} 30^{\prime} 00^{\prime \prime} \mathrm{N}$ and longitudes $5^{\circ} 0^{\prime} 0^{\prime \prime} \mathrm{E}$ and $7^{\circ} 30^{\prime} 00^{\prime \prime} \mathrm{E}$. It is one of the world's largest wetlands covering an area of approximately $70,000 \mathrm{~km}^{2}$, located in the south-south geopolitical region of Nigeria. Along the coast, the Niger Delta stretches from the Benin River in the West to Bonny River in East [18]. The region experiences very high annual rainfall ranging between 3000 to $4500 \mathrm{~mm}$ with double maxima characteristics of July and September peaks [19]. Although the Niger Delta can be roughly categorized into four ecological sub-zones (coastal barrier Islands, mangrove, freshwater swamp forest and the lowland rainforest), the mangrove is the largest and dominant ecosubzone. In terms of socio-economic development, the region could be described as being a "rich region with poor people". It is blessed with abundant crude oil and natural gas, which is the mainstay of Nigeria's economy. Apart from crude oil and natural gas, the mangroves offer a lot of biological resources on which the rural livelihood depend [19]. The relief of the area is low-lying and the rivers are influenced by tidal fluctuation [20]. A substantial part of the Niger Delta region lies at an average altitude of about $12 \mathrm{~m}$ above mean sea level. In terms of general surface features, the area falls within the coastal belt dominated by Low-Lying

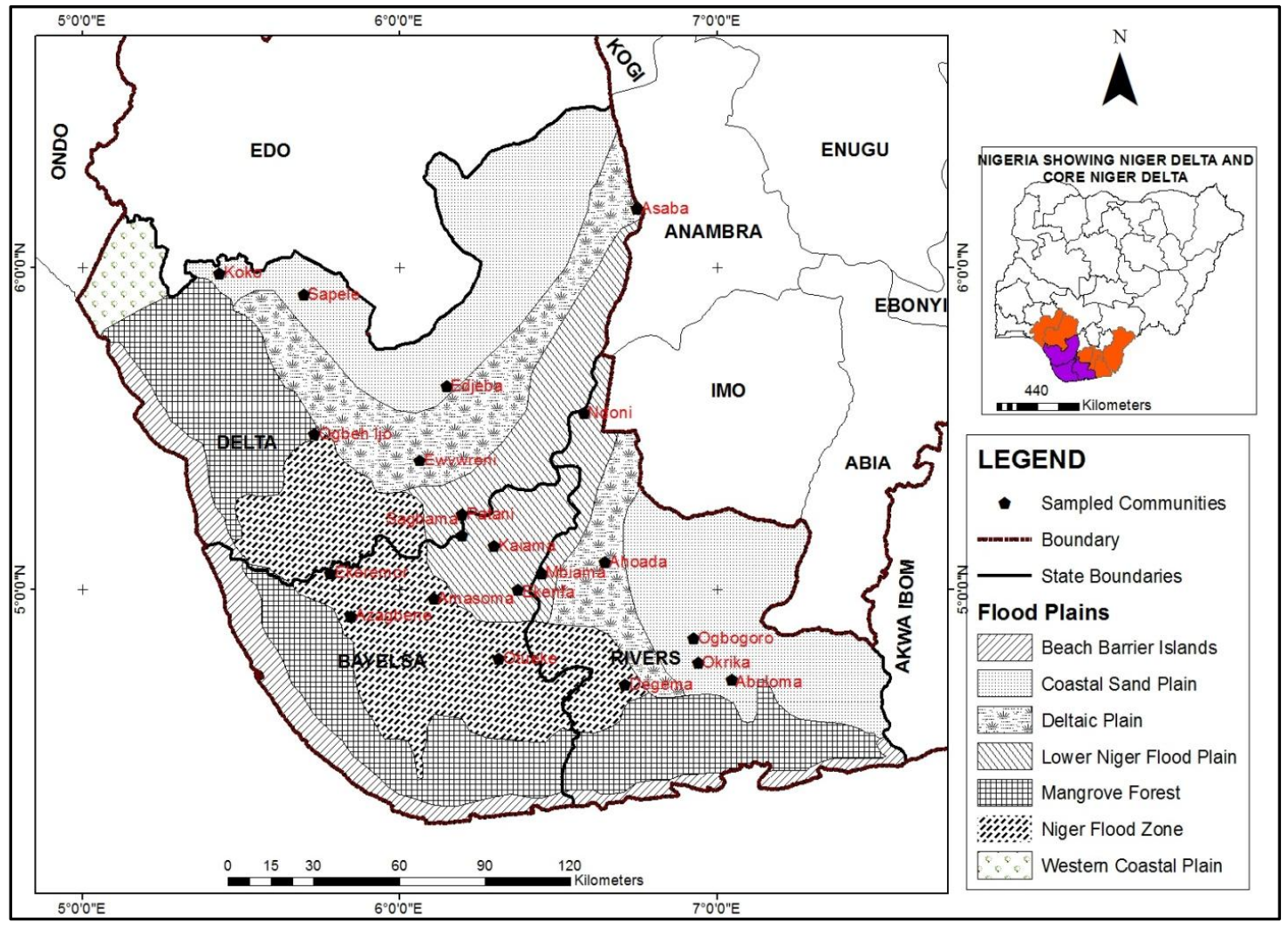

Fig. 1. Core Niger Delta 
coastal plains which structurally belong to the sedimentary formation of the recent Niger Delta $[21,22]$. The people of the Niger Delta get their source of livelihood from the natural resource around the coastal and swampy area; this is why flooding is a serious disaster for the people in the Niger Delta region. The coastline of about 560 $\mathrm{km}$ of the Niger Delta is covered with mangrove swamp. The Mangrove swamp is rich in the southernmost part of Nigeria covering over $20,000 \mathrm{~km}$ within a wetland of $70,000 \mathrm{~km}$ [23]. Similarly, the Niger Delta region is underlain by the basement complex and sedimentary rock most noticeably in the Oban and Obudu areas while the coastal areas consist mostly of sedimentary rock. Also, around the coastal area is the hydromorphic and organic soils developed on alluvial marine and fluvial marine deposits of variable texture.

Before the discovery of crude oil, agriculture was the dominant occupation of the people. Crude oil was discovered in commercial quantity in the region specifically in the present Bayelsa State in 1956 [24]. Since then oil exploration and exploitation has continued resulting in what is termed environmental destruction due to neglect and less concern of the multinational companies in environmental management in the area. Apart from environmental degradation resulting from Oil \& Gas mining activities, the Niger Delta is plagued with the problem of perennial flooding and shoreline erosion which has accounted for severe loss of lives \& properties in the region owing to its physiographic configurations. The Niger Delta with a population of over 10 million people is one of the industrial and commercial hubs of Nigeria. It is the home of Nigeria's Oil and Gas Industries and a commercial nexus in Nigeria because of its coastal location. The area is currently witnessing rapid economic growth and little or no development [19].

\section{MATERIALS AND METHODS}

790 respondents (otherwise residents) were selected; 50 heads of the household each from 5 communities each in the selected states (i.e. Bayelsa, Delta, and Rivers) including 30 NEMA and 10 SEMA (i.e. 5 BASEMA and 5 DESEMA) officials participated in the study. The multistage sampled study was in three phases. Firstly, the random sampling technique (using a blindfold) was used in the selection of the 5 prone communities from each of the 3 States. This led to the researchers consecutively picking 5 numbers from each of the three states to arrive at flood-prone communities in each of the selected core Niger Delta states.

In the second phase, the random sampling technique was used in the selection of 50 respondents from each of the 5 selected communities spread across each of the 3 selected states. This gave a sample of 250 respondents per state totalling 750 in the 3 selected states.

In the third phase, the random sampling technique was used in the selection of 30 National Emergency Management Agency (NEMA) staff or official in all three states (i.e. 10 each per state). In the fourth and final phase, random sampling was adopted in the selection of 10 SEMA officials (i.e. 5 from Bayelsa State Emergency Agency (BASEMA) and 5 from Delta State Emergency Agency (DESEMA). This constituted a sample of 780 respondents (comprising 30 NEMA officials in the three States, 10 BASEMA official and 750 residents across 5 communities in each of the three selected States) that was used for the study. Similarly, the entirety of these 15 communities in the 3 states constituted the sampling frame for the study. Furthermore, the coordinate (Northings, Eastings, and Elevation) were taken at specific locations (otherwise sampling points) across all the 15 communities using certain landmarks like a market, stream, river, bridge, school, canal, road/drainage and farmlands. The instruments for data collection for this study included Community-based Resilience Inventory (CRI), Food Security Inventory (FSI), Flood Disaster Scale (FDS) and Community Livelihood Assessment Scale (CLAS). The CRI was a 15 item self-structured instrument patterned after a four-point rating scale of "Always Available" = (AA, 4-Points) "Available" = (A, 3-Points) "Sometimes" = (S, 2-Points) and "Rarely Available" (RA, 1-Point).

Similarly, the CRI instrument consisted of two sections. Section A consists of the personal or demographic data or information of the respondents while Section B consisted of items that aided the researcher to elicit information or data on the dimensions of community resilience via mobilization, collaboration, alertness, emergency response and management.

Also, the $\mathrm{FSI}$ was another 27 items selfstructured instrument patterned after a four-point rating scale of "Always Always" (AA, 4 Points), "Always" (A, 3 Points) "Sometimes" (S, 2 Points) 
and "Sometime Applicable" (SA, 1 Point). In the same vein, the $\mathrm{FSI}$ instrument consisted of two sections. Section A consists of the personal or demographic data or information on the respondents while Section B consisted of items that elicited information or data on the extent and effect of the flood on food security.

The FDS was a 22 item self-structured instrument patterned after a four-point rating scale of "Strongly Agree" (SA, 4 Points), "Agree" (A, 3 Points), "Disagree" (D, 2 Points) and "Strongly Disagree" (SD, 1 Point). The FDS instrument also comprised of two sections. Section A consisted of the demographic data or information on the respondents while Section B consists of items on approaches to flood disaster management (via planning and right attitude). The flooded area map of these communities across Bayelsa, Delta and Rivers States (study area) were also identified and overlaid with its topographic features. Furthermore, the CLAS was a 35 item self-structured instrument patterned after a four-point rating scale of "Strongly Agree" (SA, 4 Points), "Agree" (A, 3 Points), "Disagree" (D, 2 Points), and "Strongly Disagree" (SD, 1 Point). The CLAS instrument also consisted of two sections. Section A consisted of the demographic data or information on the respondents while Section B consisted of items on livelihood and socioeconomic characteristics. Similarly, the flooded area map of these communities across the study area was also identified and overlaid with its topographic features. Descriptive statistics in the form of frequency and percentages were used to explain the results.

The Likert scale was chosen because it uses a universal method of collecting data, it is easy to understand, draw conclusions, report results and graphs from responses of the flood-prone areas of the Niger Delta. It is the best in obtaining or measuring the people's attitude towards the effects of flooding on food security, livelihood and socio-economic characteristics in the flood-prone areas.

\section{RESULTS}

\subsection{Influence of Flood Risk on Farmlands}

Table 1 indicates the extent of flood influencing the farmland/cultivated lands coverage in the core Niger Delta. Flooding brings up the issue of food insecurity and stealing of food has the highest value with $484(76.6 \%)$, basic food is scarce after all flood incident with 476 (75.3\%), households or residents find it difficult accessing food after every flooding incident with 362 $(57.3 \%)$, flood makes individuals not to gain from the crops planted in farms or gardens with 458 $(72.5 \%)$, growth and development of crops is affected when flood washes away farmlands with $442(69.9 \%)$, farmers in the communities experience very poor harvest of crops after flood incidents with 435 (68.8\%), flood rises the harvesting of immature crops with 393 (62.2\%), washing away of farmlands by flood leads to severe hunger and starvation with 391 (61.9\%), illegal trespassing into other persons farms/fishing areas increases after every flood with $384(60.8 \%)$ and households or residents find it difficult accessing food after every flooding incident with 362 (57.3\%).

It further shows that the frequency and percentage rating on the extent that flood sometimes affects the farmland/cultivated lands coverage in the core Niger Delta includes: community flood control committee distributes relief materials like foam, pillow, blankets, mosquito nets, buckets, etc. to flood victims with $392(62.1 \%)$.

\subsection{Influence of Flood on Food Security}

Table 2 indicates the extent flood level influences food security. Flood increases the issue of inadequate or insufficient food in the communities with 496 (78.5\%), flood makes it difficult for residents in the areas to freely access food with 493 (78.0\%), flood leaves individuals and households with insufficient money or fund for the purchase of food with 414 (65.5\%), flood incident increases hunger in the community with $391(61.9 \%)$, flood leads to the consumption of unhealthy food that exposes people to chronic hunger with $384(60.7 \%)$, and flood leads to individuals and households taking or pilfering with other person's food without permission (in item 16) with 336 (52.7\%).

It further shows the frequency and percentage rating on how the respondents differed or disagreed that the extent of flood risk level of a community is not applicable to influence food security includes: residents always have sufficient fund to buy food after flood incident with $509(80.5 \%)$, there is sufficient food at all times of the year in the communities with 467 $(73.9 \%)$ and flood makes individuals to continuously take insufficient food that does not meet the dietary energy requirements with 408 $(64.5 \%)$. 
Table 1. Effects of flood on farmlands/cultivated lands coverage

\begin{tabular}{|c|c|c|c|c|c|c|}
\hline \multirow[t]{2}{*}{ Extent flood affect farmlands include: } & \multicolumn{4}{|c|}{$N=632$} & \multirow[t]{2}{*}{ Total } & \multirow[b]{2}{*}{ 음 } \\
\hline & $\overline{\mathbf{A A}}$ & A & $\mathrm{S}$ & NA & & \\
\hline $\begin{array}{l}\text { Washing away of farmlands by flood leads to severe } \\
\text { hunger and starvation }\end{array}$ & $144(22.8 \%)$ & $247(39.1 \%)$ & $106(16.8 \%)$ & $135(21.4 \%)$ & $632(100 \%)$ & * \\
\hline $\begin{array}{l}\text { Farmers in the community experience very poor harvest of } \\
\text { crops after flood incidents }\end{array}$ & $272(43.0 \%)$ & $163(25.8 \%)$. & $73(11.6 \%)$ & $124(19.6 \%)$ & $632(100 \%)$ & * \\
\hline $\begin{array}{l}\text { Households or residents find it difficult accessing food after } \\
\text { every flooding incident }\end{array}$ & $159(25.2 \%)$ & $203(32.1 \%)$ & $117(18.5 \%)$ & $153(24.2 \%)$ & $632(100 \%)$ & * \\
\hline $\begin{array}{l}\text { Growth and development of crops is affected when flood } \\
\text { washes away farmlands }\end{array}$ & $213(33.7 \%)$ & $229(36.2 \%)$ & $93(14.7 \%)$ & $97(15.3 \%)$ & $632(100 \%)$ & * \\
\hline $\begin{array}{l}\text { Flood washes away the fishing nets or traps in the fishing } \\
\text { ports/gardens }\end{array}$ & $140(22.2 \%)$ & $100(15.8 \%)$ & $214(33.9 \%)$ & $178(28.2 \%)$ & $632(100 \%)$ & $\#$ \\
\hline Basic food is scarce after all flood incident & $247(39.1 \%)$ & $229(36.2 \%)$ & $84(13.3 \%)$ & $72(11.4 \%)$ & $632(100 \%)$ & * \\
\hline $\begin{array}{l}\text { Flood makes individuals not to gain from the crops planted } \\
\text { in farms or gardens }\end{array}$ & $166(26.3 \%)$ & $292(46.2 \%)$ & $77(12.2 \%)$ & $97(15.3 \%)$ & $632(100 \%)$ & * \\
\hline $\begin{array}{l}\text { Flood brings up the issue of food insecurity and stealing of } \\
\text { food in the community }\end{array}$ & $268(42.4 \%)$ & $216(34.2 \%)$ & $83(13.1 \%)$ & $65(10.3 \%)$ & $632(100 \%)$ & * \\
\hline Flood rises the harvesting of immature crops & $221(35.0 \%)$ & $172(27.2 \%)$ & $111(17.6 \%)$ & $128(20.3 \%)$ & $632(100 \%)$ & * \\
\hline $\begin{array}{l}\text { Illegal trespassing into other persons farms/fishing areas } \\
\text { increases after every flood }\end{array}$ & $171(27.1 \%)$ & $213(33.7 \%)$ & $131(20.7 \%)$ & $117(18.5 \%)$ & $632(100 \%)$ & * \\
\hline
\end{tabular}

${ }^{*}=$ Always while \#=Sometime 
Table 2. Influence of flood level on food security

\begin{tabular}{|c|c|c|c|c|c|c|}
\hline \multirow{2}{*}{$\begin{array}{l}\text { Extent flood incidents influences food security in flood- } \\
\text { prone communities }\end{array}$} & \multicolumn{4}{|c|}{$N=632$} & \multirow[t]{2}{*}{ Total } & \multirow[b]{2}{*}{$\frac{5}{\frac{0}{0}}$} \\
\hline & AA & A & $\mathbf{S}$ & NA & & \\
\hline $\begin{array}{l}\text { Flood makes it difficult for residents in the area to freely } \\
\text { access food }\end{array}$ & $278(44.0 \%)$ & $215(34.0 \%)$ & $85(13.4 \%)$ & $54(8.5 \%)$ & $632(100 \%)$ & $*$ \\
\hline $\begin{array}{l}\text { Flood increases the issue of inadequate or insufficient food } \\
\text { in the communities }\end{array}$ & $284(44.9 \%)$ & $212(33.6 \%)$ & $88(13.9 \%)$ & $48(7.6 \%)$ & $632(100 \%)$ & $*$ \\
\hline $\begin{array}{l}\text { Residents always have sufficient fund to buy food after a } \\
\text { flood incident }\end{array}$ & 37 (5.9\%) & $86(13.6 \%)$ & 207 (32.8\%) & $302(47.8 \%)$ & $632(100 \%)$ & $\#$ \\
\hline $\begin{array}{l}\text { There is sufficient food at all times of the year in the } \\
\text { communities }\end{array}$ & $79(12.5 \%)$ & $86(13.6 \%)$ & $231(36.6 \%)$ & $236(37.3 \%)$ & $632(100 \%)$ & $\#$ \\
\hline $\begin{array}{l}\text { Flood leads to the consumption of unhealthy food that } \\
\text { exposes people to chronic hunger }\end{array}$ & $129(20.4 \%)$ & $255(40.3 \%)$ & $113(17.9 \%)$ & $135(21.4 \%)$ & $632(100 \%)$ & $*$ \\
\hline $\begin{array}{l}\text { Flood leads to individuals and households taking or pilfering } \\
\text { with other person's food without permission }\end{array}$ & $149(23.6 \%)$ & $184(29.1 \%)$ & $155(24.5 \%)$ & $144(22.8 \%)$ & $632(100 \%)$ & $*$ \\
\hline $\begin{array}{l}\text { Flood makes individuals to continuously take insufficient } \\
\text { food that does not meet the dietary energy requirements }\end{array}$ & $108(17.1 \%)$ & $116(18.4 \%)$ & $196(31.0 \%)$ & $212(33.5 \%)$ & $632(100 \%)$ & $\#$ \\
\hline Flood incident increases hunger in the communities & $144(22.8 \%)$ & $247(39.1 \%)$ & $106(16.8 \%)$ & $135(21.4 \%)$ & $632(100 \%)$ & * \\
\hline $\begin{array}{l}\text { Flood leaves individuals and households with insufficient } \\
\text { money or fund for the purchase of food }\end{array}$ & $273(43.2 \%)$ & $141(22.3 \%)$ & $86(13.6 \%)$ & $132(20.9 \%)$ & $632(100 \%)$ & * \\
\hline Flood leads to the scarcity of food in the communities & $149(23.6 \%)$ & $218(34.5 \%)$ & $111(17.6 \%)$ & $154(24.4 \%)$ & $632(100 \%)$ & * \\
\hline $\begin{array}{l}\text { The washing away of farmlands have led to chronic, long- } \\
\text { lasting food insecurity in the communities }\end{array}$ & $206(32.6 \%)$ & $236(37.3 \%)$ & $85(13.4 \%)$ & $105(16.6 \%)$ & $632(100 \%)$ & * \\
\hline $\begin{array}{l}\text { Flood reduces the chances of individuals and households in } \\
\text { the communities to benefit from the agricultural produce or } \\
\text { crops planted in their farms or gardens }\end{array}$ & $128(20.3 \%)$ & $98(15.5 \%)$ & $216(34.2 \%)$ & $190(30.0 \%)$ & $632(100 \%)$ & $\#$ \\
\hline $\begin{array}{l}\text { Flood increases the inability of plants to absorb essential } \\
\text { nutrients necessary for proper growth }\end{array}$ & $168(26.6 \%)$ & $319(50.5 \%)$ & $72(11.4 \%)$ & $73(11.6 \%)$ & $632(100 \%)$ & * \\
\hline $\begin{array}{l}\text { Farmers in the communities have access to the large } \\
\text { harvest of crops after flood incidents }\end{array}$ & $125(19.8 \%)$ & $109(17.2 \%)$ & $206(32.6 \%)$ & $192(30.4 \%)$ & $632(100 \%)$ & $\#$ \\
\hline $\begin{array}{l}\text { Flooding leads to the erosion or loss of the nutritional status } \\
\text { of crops planted in the communities }\end{array}$ & 197 (31.2\%) & $254(40.2 \%)$ & $110(17.4 \%)$ & $71(11.2 \%)$ & $632(100 \%)$ & * \\
\hline
\end{tabular}




\begin{tabular}{|c|c|c|c|c|c|c|}
\hline \multirow{2}{*}{$\begin{array}{l}\text { Extent flood incidents influences food security in flood- } \\
\text { prone communities }\end{array}$} & \multicolumn{4}{|c|}{$N=632$} & \multirow[t]{2}{*}{ Total } & \multirow[b]{2}{*}{$\frac{.0}{\frac{0}{0}}$} \\
\hline & $\overline{\mathbf{A A}}$ & $\mathbf{A}$ & $\mathbf{S}$ & NA & & \\
\hline $\begin{array}{l}\text { Flood incident affects the source of income and ability of } \\
\text { individuals and households in the communities to purchase } \\
\text { and consume food with the daily required energy intake }\end{array}$ & $257(40.7 \%)$ & $152(24.1 \%)$ & $88(13.9 \%)$ & $135(21.4 \%)$ & $632(100 \%)$ & * \\
\hline $\begin{array}{l}\text { Flood increases food insecurity, unavailability of staple food } \\
\text { and malnutrition }\end{array}$ & 277 (43.8\%) & $218(34.5 \%)$ & $84(13.3 \%)$ & $53(8.4 \%)$ & $632(100 \%)$ & * \\
\hline
\end{tabular}

Table 3. Impact of flood level of a community on livelihood

\begin{tabular}{|c|c|c|c|c|c|c|}
\hline \multirow{2}{*}{$\begin{array}{l}\text { The extent flood risk level influences the livelihood to } \\
\text { include: }\end{array}$} & \multicolumn{4}{|c|}{$N=632$} & \multirow[t]{2}{*}{ Total } & \multirow[b]{2}{*}{$\frac{\frac{0}{0}}{\frac{0}{0}}$} \\
\hline & SA & A & D & SD & & \\
\hline $\begin{array}{l}\text { Flood incidents increase the possible outbreak of malaria, } \\
\text { typhoid fever, diarrhoea, etc. which affects the livelihood of the } \\
\text { people }\end{array}$ & $244(38.6 \%)$ & $226(35.8 \%)$ & $84(13.3 \%)$ & $78(12.3 \%)$ & $632(100 \%)$ & $*$ \\
\hline $\begin{array}{l}\text { The livelihood of people/residents is affected when their } \\
\text { occupation is endangered by flood incidents }\end{array}$ & $165(26.1 \%)$ & 322 (50.9\%). & $65(10.3 \%)$ & $80(12.7 \%)$ & $632(100 \%)$ & $*$ \\
\hline $\begin{array}{l}\text { Flood incidents reduce the source of income of } \\
\text { residents/individuals }\end{array}$ & $278(44.0 \%)$ & $215(34.0 \%)$ & $85(13.4 \%)$ & $54(8.5 \%)$ & $632(100 \%)$ & * \\
\hline $\begin{array}{l}\text { The traditional occupation or employment of the people like } \\
\text { boat carving is lost during and after the flooding incident }\end{array}$ & $216(34.2 \%)$ & 187 (29.6\%) & $99(15.7 \%)$ & $130(20.6 \%)$ & $632(100 \%)$ & $*$ \\
\hline $\begin{array}{l}\text { Fishing as a means of employment in the communities is lost } \\
\text { during and after the flooding incident }\end{array}$ & $171(27.1 \%)$ & 213 (33.7\%) & $131(20.7 \%)$ & $117(18.5 \%)$ & 632 (100\%) & * \\
\hline $\begin{array}{l}\text { The washing away of farmlands reduces the chances of the } \\
\text { people engaging in farming or agriculture }\end{array}$ & $163(25.8 \%)$ & 199 (31.5\%) & $144(22.8 \%)$ & $126(19.9 \%)$ & $632(100 \%)$ & * \\
\hline $\begin{array}{l}\text { The washing away of farmlands reduces the chances of the } \\
\text { people harvesting their farm products }\end{array}$ & $267(42.2 \%)$ & $150(23.7 \%)$ & $111(17.6 \%)$ & $104(16.5 \%)$ & $632(100 \%)$ & $*$ \\
\hline $\begin{array}{l}\text { The increased feeling of raffia palm trees due to flooding } \\
\text { reduces the occupation of the people as gin producers }\end{array}$ & $197(31.2 \%)$ & $113(17.9 \%)$ & $184(29.1 \%)$ & $138(21.8 \%)$ & $632(100 \%)$ & $\#$ \\
\hline
\end{tabular}




\begin{tabular}{|c|c|c|c|c|c|c|}
\hline \multirow{2}{*}{$\begin{array}{l}\text { The extent flood risk level influences the livelihood to } \\
\text { include: }\end{array}$} & \multicolumn{4}{|c|}{$N=632$} & \multirow[t]{2}{*}{ Total } & \multirow[b]{2}{*}{ 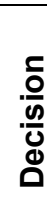 } \\
\hline & SA & $\mathbf{A}$ & D & SD & & \\
\hline $\begin{array}{l}\text { The increased feeling of raffia palm trees due to flooding } \\
\text { reduces the income the people generate from gin production }\end{array}$ & $313(49.5 \%)$ & $197(31.2 \%)$ & $71(11.2 \%)$ & $51(8.1 \%)$ & $632(100 \%)$ & * \\
\hline $\begin{array}{l}\text { The increased feeling of raffia palm trees due to flooding } \\
\text { reduces employment in the gin production industry generates } \\
\text { by the people }\end{array}$ & $108(17.1 \%)$ & $167(26.4 \%)$ & $166(26.3 \%)$ & $191(30.2 \%)$ & $632(100 \%)$ & $\#$ \\
\hline $\begin{array}{l}\text { The washing away of farmlands reduces the chances of the } \\
\text { people selling or getting income from their farm products }\end{array}$ & $174(27.5 \%)$ & $137(27.7 \%)$ & $173(27.4 \%)$ & $148(23.4 \%)$ & $632(100 \%)$ & $\#$ \\
\hline $\begin{array}{l}\text { The increased feeling of trees due to flooding reduces the } \\
\text { occupation of the people as timber merchants }\end{array}$ & $183(29.0 \%)$ & 201 (31.8\%). & $142(22.5 \%)$ & $106(16.8 \%)$ & $632(100 \%)$ & * \\
\hline $\begin{array}{l}\text { Frequent flood incidents destroy trees and buildings which } \\
\text { provides income for residents in the communities }\end{array}$ & $171(27.1 \%)$ & 179 (28.3\%) & $167(26.4 \%)$ & $115(18.2 \%)$ & $632(100 \%)$ & $*$ \\
\hline $\begin{array}{l}\text { The intensity of flooding leads to the felling of trees which } \\
\text { reduces the income the people generates from timber } \\
\text { production }\end{array}$ & 201 (31.8\%) & 187 (29.6\%) & $139(22.0 \%)$ & $105(16.6 \%)$ & $632(100 \%)$ & * \\
\hline $\begin{array}{l}\text { The washing away of farmlands reduces the probability of } \\
\text { eating healthy foods that can enhance their livelihood }\end{array}$ & $191(30.2 \%)$ & $156(24.7 \%)$ & $151(23.9 \%)$ & $134(31.2 \%)$ & $632(100 \%)$ & * \\
\hline $\begin{array}{l}\text { The consumption of unhealthy food seriously affects the } \\
\text { livelihood of individuals/residents in the communities }\end{array}$ & $172(27.2 \%)$ & $152(24.1 \%)$ & $162(25.6 \%)$ & $146(23.1 \%)$ & $632(100 \%)$ & * \\
\hline $\begin{array}{l}\text { The living conditions and structure of buildings deteriorate from } \\
\text { the incident of flood }\end{array}$ & $126(19.9 \%)$ & $222(35.1 \%)$ & $160(25.3 \%)$ & $124(19.6 \%)$ & $632(100 \%)$ & * \\
\hline $\begin{array}{l}\text { Residents lose the capacity to maintain themselves as flood } \\
\text { incidents makes them vulnerable or helpless }\end{array}$ & $163(25.8 \%)$ & $248(39.2 \%)$ & $121(19.1 \%)$ & $100(15.8 \%)$ & $632(100 \%)$ & $*$ \\
\hline $\begin{array}{l}\text { Flood affects the means of support of individuals and } \\
\text { community members }\end{array}$ & $162(25.6 \%)$ & 198 (31.3\%) & $152(24.1 \%)$ & $120(19.0 \%)$ & $632(100 \%)$ & \\
\hline $\begin{array}{l}\text { The impact of flooding makes the economy of } \\
\text { individuals/residents in the communities very difficult }\end{array}$ & 179 (28.3\%) & $174(27.5 \%)$ & $156(24.7 \%)$ & $123(19.5 \%)$ & $632(100 \%)$ & \\
\hline $\begin{array}{l}\text { The loss of the source of income makes even the active adult } \\
\text { population more interested in fighting for self-survival than } \\
\text { carter for even children or the aged }\end{array}$ & $141(22.3 \%)$ & $262(41.5 \%)$ & $112(17.7 \%)$ & $117(18.5 \%)$ & $632(100 \%)$ & \\
\hline
\end{tabular}




\begin{tabular}{|c|c|c|c|c|c|c|}
\hline \multirow{2}{*}{$\begin{array}{l}\text { The extent flood risk level influences the livelihood to } \\
\text { include: }\end{array}$} & \multicolumn{4}{|c|}{$N=632$} & \multirow[t]{2}{*}{ Total } & \multirow[b]{2}{*}{$\frac{\frac{5}{0}}{\frac{9}{0}}$} \\
\hline & SA & A & D & SD & & \\
\hline $\begin{array}{l}\text { Flood incidents decrease, cuts or reduce the means of support } \\
\text { for especially the children and the aged in the communities }\end{array}$ & $258(40.8 \%)$ & 155 (24.5\%) & $95(15.1 \%)$ & $124(19.6 \%)$ & $632(100 \%)$ & \\
\hline $\begin{array}{l}\text { Seeking for means of survival after the loss of the source of } \\
\text { income wrongly portrays the active adult population in the } \\
\text { communities less-sensitive to the difficulty, needs (like feeding, } \\
\text { clothing, shelter, etc.) of children and the aged }\end{array}$ & $159(25.2 \%)$ & $229(26.2 \%)$ & $106(16.8 \%)$ & $138(21.8 \%)$ & $632(100 \%)$ & \\
\hline $\begin{array}{l}\text { Flood incidents wash away the stored crops, gin, and other } \\
\text { products of residents in the communities }\end{array}$ & 205 (32.4\%) & 237 (37.5\%) & $90(14.2 \%)$ & $100(15.8 \%)$ & $632(100 \%)$ & \\
\hline $\begin{array}{l}\text { The incident of flood leads to acute food insecurity which } \\
\text { affects the livelihood of residents in the communities }\end{array}$ & $251(39.7 \%)$ & 227 (35.9\%) & $80(12.7 \%)$ & $74(11.7 \%)$ & $632(100 \%)$ & \\
\hline $\begin{array}{l}\text { Flood affects the means of support of individuals and } \\
\text { community members }\end{array}$ & $162(25.6 \%)$ & $198(31.3 \%)$ & $152(24.1 \%)$ & $120(19.0 \%)$ & $632(100 \%)$ & $*$ \\
\hline $\begin{array}{l}\text { The impact of flooding makes the economy of } \\
\text { individuals/residents in the communities very difficult }\end{array}$ & $179(28.3 \%)$ & $174(27.5 \%)$ & $156(24.7 \%)$ & $123(19.5 \%)$ & $632(100 \%)$ & $*$ \\
\hline $\begin{array}{l}\text { The loss of the source of income makes even the active adult } \\
\text { population more interested in fighting for self-survival than } \\
\text { carter for even children or the aged }\end{array}$ & $141(22.3 \%)$ & $262(41.5 \%)$ & $112(17.7 \%)$ & $117(18.5 \%)$ & $632(100 \%)$ & $*$ \\
\hline $\begin{array}{l}\text { Flood incidents decrease, cuts or reduce the means of support } \\
\text { for especially the children and the aged in the communities }\end{array}$ & $258(40.8 \%)$ & $155(24.5 \%)$ & $95(15.1 \%)$ & $124(19.6 \%)$ & $632(100 \%)$ & $*$ \\
\hline $\begin{array}{l}\text { Seeking for means of survival after the loss of the source of } \\
\text { income wrongly portrays the active adult population in the } \\
\text { communities less-sensitive to the difficulty, needs (like feeding, } \\
\text { clothing, shelter, etc.) of children and the aged }\end{array}$ & $159(25.2 \%)$ & $229(26.2 \%)$ & $106(16.8 \%)$ & $138(21.8 \%)$ & $632(100 \%)$ & $\star$ \\
\hline $\begin{array}{l}\text { Flood incidents wash away the stored crops, gin, and other } \\
\text { products of residents in the communities }\end{array}$ & $205(32.4 \%)$ & 237 (37.5\%) & $90(14.2 \%)$ & $100(15.8 \%)$ & $632(100 \%)$ & * \\
\hline $\begin{array}{l}\text { The incident of flood leads to acute food insecurity which } \\
\text { affects the livelihood of residents in the communities }\end{array}$ & $251(39.7 \%)$ & 227 (35.9\%) & $80(12.7 \%)$ & $74(11.7 \%)$ & $632(100 \%)$ & $*$ \\
\hline
\end{tabular}

\footnotetext{
${ }^{*}=$ Agree while \#=Disagree
} 
Table 4. Influence of socio-economic characteristics on food security and livelihood of people in the flood-prone areas of core Niger Delta

\begin{tabular}{|c|c|c|c|c|c|c|}
\hline \multirow{2}{*}{$\begin{array}{l}\text { The influence of socio-economic characteristics on food } \\
\text { security and livelihood include }\end{array}$} & \multicolumn{4}{|c|}{$\mathbf{N}=632$} & \multirow[t]{2}{*}{ Total } & \multirow[b]{2}{*}{ 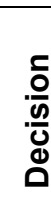 } \\
\hline & SA & A & D & SD & & \\
\hline There is always sufficient fund to buy food after a flood incident & $163(25.8 \%)$ & $199(31.5 \%)$ & $144(22.8 \%)$ & $126(19.9 \%)$ & $632(100 \%)$ & * \\
\hline $\begin{array}{l}\text { The washing away of farmlands reduces the fund to be gained } \\
\text { from the selling of farm products }\end{array}$ & $257(40.7 \%)$ & $150(23.7 \%)$ & $116(18.4 \%)$ & $109(17.2 \%)$ & $632(100 \%)$ & * \\
\hline $\begin{array}{l}\text { Flood leaves individuals and households with insufficient money } \\
\text { to purchase food }\end{array}$ & $194(30.7 \%)$ & $123(19.5 \%)$ & $170(26.9 \%)$ & $145(22.9 \%)$ & $632(100 \%)$ & * \\
\hline $\begin{array}{l}\text { Flood incident affects individuals and households' source of } \\
\text { income }\end{array}$ & $257(40.7 \%)$ & $198(31.3 \%)$ & $100(15.8 \%)$ & $77(12.2 \%)$ & $632(100 \%)$ & * \\
\hline $\begin{array}{l}\text { Flood incident affects the ability of individuals and households in } \\
\text { the communities to purchase food }\end{array}$ & $151(23.9 \%)$ & $164(25.9 \%)$ & $148(23.5 \%)$ & $169(26.7 \%)$ & $632(100 \%)$ & \# \\
\hline $\begin{array}{l}\text { Inability to get money to repair damaged crop/fish farms affects } \\
\text { households' survival months after the floods }\end{array}$ & $203(32.1 \%)$ & $153(24.2 \%)$ & $133(21.0 \%)$ & $143(22.6 \%)$ & $632(100 \%)$ & \\
\hline $\begin{array}{l}\text { Flood affects households or residents' investments in other } \\
\text { areas }\end{array}$ & $193(30.5 \%)$ & $216(34.2 \%)$ & $128(20.3 \%)$ & $95(15.0 \%)$ & $632(100 \%)$ & \\
\hline $\begin{array}{l}\text { The loss of occupations like farming, fishing, etc. due to flooding } \\
\text { affects the livelihood of individuals or households }\end{array}$ & $178(28.2 \%)$ & $189(29.9 \%)$ & $145(22.9 \%)$ & $120(19.0 \%)$ & $632(100 \%)$ & \\
\hline $\begin{array}{l}\text { Losing occupation and source of income from flooding leads to } \\
\text { difficulty in caring for the children }\end{array}$ & $210(33.2 \%)$ & $175(27.7 \%)$ & $135(21.4 \%)$ & $112(17.7 \%)$ & $632(100 \%)$ & \\
\hline $\begin{array}{l}\text { Flood worsens the poverty and inability of low-income } \\
\text { individuals and households to buy rising foods }\end{array}$ & $214(33.9 \%)$ & $165(26.1 \%)$ & $132(20.9 \%)$ & $121(19.9 \%)$ & $632(100 \%)$ & \\
\hline
\end{tabular}


It can also be seen that flood increases food insecurity, unavailability of staple food and malnutrition with 495 (78.3\%), flood increases the inability of plants to absorb essential nutrients necessary for proper growth with 487 (77.1\%), flooding leads to the erosion or loss of the nutritional status of crops planted in the communities with 451 (71.4\%), the washing away of farmlands have led to chronic, longlasting food insecurity in the communities with $442(69.9 \%)$, flood incident affects the source of income and ability of individuals and households in the communities to purchase and consume food with the daily required energy intake with $409(64.8 \%)$, and flood leads to the scarcity of food in the communities with 367 (58.1\%).

It further shows that the frequency and percentage rating on how the respondents differed or disagreed that the flood level of a community is not applicable to influence food security includes: flood reduces the chances of individuals and households in the communities to benefit from the agricultural produce or crops planted in their farms or gardens with 406 $(64.2 \%)$ and farmers in the communities have access to large harvest of crops after flood incidents with 398 (63.0\%).

\subsection{Influence of Flood on Livelihood}

Table 3 presents the extent of flood level of communities influencing livelihood in the core Niger Delta and these included the increased felling of raffia palm trees due to flooding reduces the income the people generate from gin production with $510(80.7 \%)$, flood incidents reduces the source of income of residents/individual with 493 (78.0\%), livelihood of people/residents is affected when their occupation is endangered by flood incidents with $487(77.0 \%)$, flood incidents increase the possible outbreak of malaria, typhoid fever, diarrhoea, etc. which affects the livelihood of the people with $470(74.4 \%)$, the washing away of farmlands reduces the chances of the people harvesting their farm products with 417 (65.9\%), the traditional occupation or employment of the people like boat carving is lost during and after flooding incident with $(63.8 \%)$, fishing as a means of employment in the communities is lost during and after flooding incident with 384 $(60.8 \%)$ and the washing away of farmlands reduces the chances of the people engaging in farming or agriculture with 362 (57.3\%).

It further shows that the respondents disagreed that the extent flood level of communities influence livelihood in the core Niger Delta includes: the increased felling of raffia palm trees due to flooding reduces employment in the gin production industry generated for the people with $357(56.5 \%)$, and the increased killing of raffia palm trees due to flooding reduces the occupation of the people as gin producers with $310(48.9 \%)$.

Furthermore, residents lose the capacity to maintain themselves as flood incidents makes them vulnerable or helpless with 411 (65.0\%), the intensity of flooding leads to the felling of trees which reduces the income generated by the people from timber production with 388 (61.4\%), the increased killing of trees due to flooding reduces the occupation of the people as timber merchants with $384(60.8 \%)$, frequent flood incidents destroys the trees and buildings which provides income for residents of communities with $350(55.4 \%)$, the living conditions and structure of buildings deteriorate from the incident of flood with $348(55.0 \%)$, the washing away of farmlands reduces the probability of eating healthy foods that can enhance their livelihood with 347 (54.9\%), and the consumption of unhealthy food seriously affects the livelihood of individuals/residents in the communities with $324(51.3 \%)$.

It further shows that the respondents disagreed that the extent flood level of communities influence the livelihood in the core Niger Delta includes: the washing away of farmlands reduces the chances of the people selling or getting income from their farm products with 321 $(50.8 \%)$.

Also, the incident of flood leads to acute food insecurity which affects the livelihood of residents in the communities with 478 (75.6\%), flood incidents washes away the stored crops, gin and other products of residents in the communities with 442 (69.9\%), flood incidents decreases, cuts or reduces the means of support for especially the children and the aged in the communities with $413(65.3 \%)$, the loss of the source of income makes even the active adult population to be more interested in fighting for self-survival than carter for even children or the aged with 403 $(63.8 \%)$, seeking for means of survival after the loss of the source of income wrongly portrays the active adult population in the communities lesssensitive to the difficulty, needs (like feeding, clothing, shelter, etc.) of children and the aged with $388(61.4 \%)$, flood affects the means of support of individuals and communities' 
members with $360(56.9 \%)$, and the impact of flooding makes the economy of individuals/ residents in communities very difficult with 353 $(55.8 \%)$.

\subsection{Influence of Socioeconomic Characteristics on Food Security and Livelihood}

Table 4 shows how the respondents agreed that socio-economic characteristics of residents' influence food security and livelihood of people in the flood-prone areas of Core Niger Delta. The result indicates that respondents who believe that flood incident affects individuals and households' source of income are highest with $455(72.0 \%)$ and those who believed that the washing away of farmlands reduces the fund to be gained from the selling of farm products accounted for 407 (64.4\%).

The result further indicates as follows: there is always sufficient fund to buy food after flood incident with 362 (57.3\%), and flood leaves individuals and households with insufficient money to purchase food with 317 (50.2\%).

It further shows how the respondents disagreed that socio-economic characteristics of residents' influence food security and livelihood of people in the flood-prone areas of Core Niger Delta. For instance, $317(50.2 \%)$ disagreed that flood incident affects the ability of individuals and households to purchase food.

Flood affects households or residents investments in other areas with $409(64.7 \%)$, losing occupation and source of income from flooding leads to difficulty in caring for the children with $385(60.9 \%)$, flood worsens the poverty and inability of low-income individuals and households to buy the rising foods with 379 $(60.0 \%)$, the loss of occupations like farming, fishing, etc. due to flooding affects the livelihood of individuals or households with 367 (58.1\%), and inability to get money to repair damaged crop/fish farms affects households survival months after the floods with 356 (56.3\%).

\section{DISCUSSION}

Deductively, the yearly occurrence of flooding has led to the devastation or destruction of a large expanse of land including cultivated farmlands like that witnessed in Kolaware Community in Patani Local Government Area of
Delta State were the 2018 flooding incidents led to the loss of their major crops like yam, plantain, okra and cocoyam. Also, the extent of the flood that occurred in Akinima community in Ahoada West Local Government Area of Rivers State led to the destruction of crops like plantain, cassava, banana, etc. Findings revealed that the extent flood always affect the farmland/cultivated lands coverage in the core Niger Delta includes: flood brings up the issue of food insecurity and stealing of food, basic food is scarce after all flood incident, households or residents find it difficult accessing food after every flooding incident, flood makes individuals not to gain from the crops planted in farms or gardens, growth and development of crops is affected when flood washes away farmlands, farmers in the communities experience very poor harvest of crops after flood incidents, flood rises the harvesting of immature crops, washing away of farmlands by flood leads to severe hunger and starvation, illegal trespassing into other persons farms/fishing areas increases after every flood, and households or residents find it difficult accessing food after every flooding incident.

These findings aligns with the study by Samuel et al. [25] which found that the common flood impacts include disruption of movement (14.5\%), damage to roads $(13.9 \%)$, loss of valuable properties $(13.7 \%)$, loss or washing away of farmlands (13.1\%) and environmental degradation/pollution $(11.5 \%)$ which depicts the severity of the flood event which has affected virtually the income and livelihood of the proportions of households or families. In line with this, UNISDR [26] emphasized the construction of roads, dams, flood levies or ocean wave barriers to tackling the eminent washing away of farmlands and the attendant food scarcity/ shortage, starvation, and poor harvest.

The result revealing that the extent flood level of a community always influence food security in the sense that flood increases the issue of inadequate or insufficient food in the communities, flood makes it difficult for residents in the area to freely access food, flood leaves individuals and households with insufficient money or fund for the purchase of food, flood incident increases hunger in the communities, flood leads to the consumption of unhealthy food that exposes people to chronic hunger, flood leads to individuals and households taking or pilfering with other person's food without permission, flood increases food insecurity, unavailability of staple food and malnutrition, 
flood increases the inability of plants to absorb essential nutrients necessary for proper growth, flooding leads to the erosion or loss of the nutritional status of crops planted in the communities, the washing away of farmlands have led to chronic, long-lasting food insecurity in the communities, flood incident affects the source of income and ability of individuals and households in the communities to purchase and consume food with the daily required energy intake, and flood leads to the scarcity of food in the communities.

These findings conforms with earlier findings by Bello and Ogedengbe [27] who stated that the direct impacts of flooding include: health-related problems, injuries, loss of farmlands, farm produce, income, malnutrition from consuming poorly harvested foods, structural and household properties, and the outbreak of epidemics which threatens the health of individuals, families and survivors to the flood menace.

Furthermore, findings showed that residents always have sufficient fund to buy food after flood incident, there is sufficient food at all times of the year in the communities, flood makes individuals to continuously take insufficient food that does not meet the dietary energy requirements, flood reduces the chances of individuals and households in the community to benefit from the agricultural produce or crops planted in their farms or gardens, and farmers in the communities have access to large harvest of crops after flood incidents. This finding differs from the study by Adelekan [28] on the vulnerability of poor urban coastal communities to flooding in Lagos, Nigeria, which revealed that: shortage of potable water, poor harvest, scarcity of food, low-quality nutrition, increased incidence of water-borne diseases, and disruptions of social and economic life of the people were indirect impacts of flooding. This menace leaves flood victims or survivors severely traumatized, and many of them experiencing symptoms of posttraumatic stress disorder (PTSD), depression, and anxiety $[29,30]$.

Findings from the study further revealed that the increased felling of raffia palm trees due to flooding reduces the income being generated from gin production, flood incidents reduces the source of income of residents/individuals, livelihood of people/residents is affected when their occupation is endangered by flood incidents, flood incidents increase the possible outbreak of malaria, typhoid fever, diarrhoea, etc. which affects the livelihood of the people, the washing away of farmlands reduces the chances of the people harvesting their farm products, the traditional occupation or employment of the people like boat carving is lost during and after flooding incident, fishing as a means of employment in the communities is lost during and after flooding incident, and the washing away of farmlands reduces the chances of the people engaging in farming or agriculture were the extent of flood level of communities influences livelihood in the core Niger Delta.

\section{CONCLUSION AND RECOMMENDA- TIONS}

Flood hazard in the core Niger Delta is real. The study has shown that over time, food security, livelihood and socio-economic characteristics of flood-prone areas of the core Niger Delta has been negatively impacted by flooding. Evidence from the study revealed that floods have destroyed farmlands and other sources of livelihood leading to food insecurity, income reduction, and poor livelihood among the residents of the core Niger Delta States. The frequency and magnitude of flood determined its intensity in the communities while the location of a community does not determine the influence of the flood level on the livelihood and food security of such community in the study area. Finally, the study has also shown that the socioeconomic characteristics of residents (i.e. individuals and households) in flood-prone communities did not determine the influence of flood on their food security and livelihood.

The study, therefore, suggested the following recommendations:

1. Communities should advocate, promote and inculcate the spirit of the commitment of individuals and households towards the continued and holistic development (via social, economic, health, and infrastructural), food security, and increased livelihood in flood-prone communities.

2. Communities should increase their investment in practices (like training, information dissemination, capacity building, etc.) that will help and stimulate individual's interest in contributing their resources, materials and expertise towards the mitigation of flood impacts. 
3. The Ministry of Agriculture should ensure that smart agriculture is adopted as a way out to resolve the issue of flood-induced food insecurity. This will enhance the knowledge of local farmers in using new and improved inputs and techniques to be utilized for planting crops that can be harvested before the arrival of the flood.

4. The Governments (federal and state) should empower and fund its agencies (NEMA and SEMA) to enable them to provide relief materials, clear or maintain drains, and use indigenous strong bamboo or other wooden planks to repair and strengthen houses and walkways during flooding.

5. NEMA, SEMA and other emergency agencies should proactively embark on regular sensitization, meetings, training, programmes, and funding tended to holistically build the capacity of the NGOs, flood control committees, residents, and households in flood inclined areas. Structural measures like dams, culverts, drainages, and ditches should be constructed by government and her intervention agencies to accommodate and reduce the runoff or overflow of floodwaters which causes severe social, economic and infrastructural damages or impacts from this disaster.

\section{COMPETING INTERESTS}

Authors have declared that no competing interests exist.

\section{REFERENCES}

1. IPCC (International Panel on Climate Change). Fourth assessment report. Cambridge: Cambridge University Press; 2007.

2. Jeronim C, Panagiotis K, Marco K, Mark S. A model of vulnerability to food insecurity. ESA Working Paper No. 10-03. Agricultural Development Economics Division; 2010

3. Nwaobiala CU, Nwosu IE. Effect of climate change on cassava farmers' output in Cross River State, Nigeria. International Journal of Agric \& Rural Development. 2014;17(1):1628-1634.

4. FAO (Food and Agriculture Organization). Climate change in Africa. The threat to agriculture.

Available:http://www.fao.org.africa; 2009
5. BNRCC (Building Nigeria's Response to Climate Change). Learning from experience-community-based adaptation to Climate Change in Nigeria. Produced with the Support of the Government of Canada and Canadian International Developing Agency (CIDA). 2012;16.

6. Gichere, et al. Effects of drought and floods on crop and animal losses and socioeconomic status of households in the Lake Victoria Basin of Kenya. Journal of Emerging Trends in Economics and Management Sciences (JETEMS). 2013;4 (1):31-41.

7. Khatri-Chatri A, Maharjan KL. Food security and coping strategies in rural areas of Nepal: A case study of Dailekh district in mid-Western development region. Journal of International Development and Cooperation. 2006;12: 25-45.

8. Alam, et al. Hazards, food insecurity and human displacement in rural riverine Bangladesh: Implication for policy. International Journal of Disaster Risk Reduction; 2019.

9. Armah FA, Yawson DO, Yengoh GT, Odoi JO, Afrifa EKA. Impact of floods on livelihoods and vulnerability of natural resource dependent communities in Northern Ghana. Water. 2010;2: 120-139.

10. McCuster B, Carr ER. The co-production of livelihoods and landuse change: Case studies from South Africa and Ghana. Geoforum. 2006;37(5):790-804.

11. Yaro JA. Theorizing food insecurity: Building a livelihood framework for researching food insecurity. Nor. Geogr. Tidsskr. 2004;58:23-37.

12. Abid M, Schilling J, Scheffran J, Zulfiqar F. Climate change vulnerability, adaptation and risk perceptions at farm level in Punjab, Pakistan. Science of Total Environment. 2016;547:447-46.

13. GOP. Economic survey of Pakistan 201314. Islamabad, Pakistan: Ministry of Food and Agriculture. Finance Division, Economic Advisor's Wing; 2014

14. Ahmed UI, Ying L, Bashir MK, Abid M, Zulfiqar F. Status and determinants of small farming households' food security and role of market access in enhancing food security in rural Pakistan. PLoS ONE. 2017;12(10).

15. Abosede OB. Challenges to food security in Nigeria's oil-rich Niger Delta region. Kujenga-Amani; 2017. 
16. Agbonkhese, et al. Road traffic accidents in Nigeria: Causes and preventive measures. Civil and Environmental Research. 2013;3(13).

17. Agbonkhese, et al. Flood menace in Nigeria: Impacts, remedial and management strategies. Civil and Environmental Research. 2014;6(4).

18. Iyalla TM. Environmental and hydrogeological mapping: A requirement for the Niger Delta development planning. Technical paper Presented to the Nigeria Society of Engineers. Technical Session in Port Harcourt. 2001;5.

19. Mmom PC, Aifesehi PEE. Vulnerability and resilience of Niger Delta coastal communities to flooding. IOSR Journal of Humanities and Social Science (IOSRJHSS). 2013;10(6):27-33.

Available:www.iosrjournals.org

20. Adegoke, et al. Geology of the Niger Delta Basin in Adegoke OS, Oyebamiji AS, Sterloff PL, Ulu OK. (Eds), Cenozoic Foraminfera and Calcareous Nannofossil Biostratigraphy of the Niger Delta. Published by Elsevier 2017 Edition. 2017;25-66.

21. Umeuduji JE, Aiseuebeogun A. Relief and drainage, in Oyegun CU, Adeyemo A. (eds). Land and people of Rivers State. River Side Communication Port-Harcourt; 1999.

22. Arokoyu SB, Ukpere DRT. Access to safe water supply and sanitation in lower Orashi River Basin, Rivers State, Nigeria. ARPN
Journal of Science and Technology. 2014; 4(11):639-646.

23. Ekubo AA, Abowei JFN. Review of some water quality management principles in culture fisheries. Research Journal of Applied Sciences, Engineering and Technology. 2011;3:1342-1357.

24. Omofonmwan SI, Odia LO. Oil exploitation and conflict in the Niger-Delta; 2009.

25. Samuel, et al. A post-disaster assessment of riverine communities impacted by a severe flooding event. Ghana Journal of Geography. 2017;9(1):17-41.

26. UNISDR. Hyogo framework for action 2005-2015: Building the resilience of nations and communities to disasters. Switzerland: UNISDR, United Nations, Geneva; 2010.

27. Bello IE, Ogedegbe SO. Geospatial analysis of flood problems in Jimeta Riverine community of Adamawa State, Nigeria. Journal of Environment and Earth. 2015;5(12):32-45.

28. Adelekan IO. Vulnerability of poor urban coastal communities to flooding in Lagos, Nigeria. Environment and Urbanization. 2010;22:433-450.

29. Mason, et al. The psychological impact of exposure to floods. Psychology, Health \& Medicine. 2010;15(1):61-73.

30. Jha AK, Bloch R, Lamond J. Cities and flooding: A guide to integrated urban flood risk management for the $21^{\text {st }}$ century. World Bank, Washington. 2012; 134-161.

(c) 2020 Week and Wizor; This is an Open Access article distributed under the terms of the Creative Commons Attribution License (http://creativecommons.org/licenses/by/4.0), which permits unrestricted use, distribution, and reproduction in any medium, provided the original work is properly cited.

Peer-review history:

The peer review history for this paper can be accessed here: http://www.sdiarticle4.com/review-history/53627 